\title{
The impact of different levels of nitrogen fertilizer on maize hybrids performance under two different environments
}

\author{
Muhammad Imran ${ }^{1,2 *}$, Amjed Ali1 ${ }^{1}$ Muhammad Ehsan Safdar ${ }^{1}$ \\ ${ }^{1}$ Department of Agronomy, College of Agriculture, University of Sargodha, Punjab, Pakistan \\ ${ }^{2}$ Department of Agricultural and Biological Engineering, University of Florida, Gainesville, Florida, USA
}

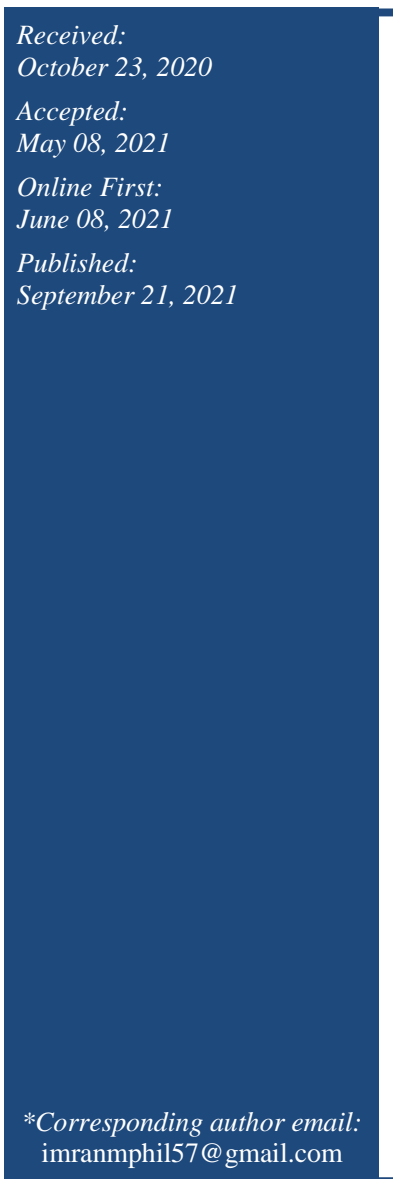

\begin{abstract}
A field experiment was conducted at Agriculture Research Farm, College of agriculture, University of Sargodha and National Agricultural Research Centre, Islamabad to compare maize hybrids $(\mathrm{H})$ and nitrogen $(\mathrm{N})$ rates, growth, yield and yield components, using a split plot design with three replications in 2017 and 2018. The main plots were supplemented with one of the following levels of $\mathrm{N}\left(\mathrm{kg} \mathrm{ha}^{-1}\right.$ : 100 (N1), 175 (N2), N3 (250), N4 (325), and N5 (400) using three different hybrids (H), H1 (P-3939), H2 (30-T-60), and H3 (30-Y-87) in the sub-plots. Data were analyzed using the MIXED procedures of SAS. The statistical models included the individual effects of $\mathrm{N}$ and $\mathrm{H}$, the interactions between $\mathrm{N}$ and $\mathrm{H}$, and the random effect of the year. Orthogonal polynomial contrasts were constructed to determine the optimum level of $\mathrm{N}$. The yield and yield components were improved at $325 \mathrm{~kg} \mathrm{~N}^{-1}$ with significant effects on maximum plant height, number of grains per cob, number of grains per $\mathrm{m}^{2}$ and grain yield. The results revealed that yield, total number of grains $\mathrm{m}^{-2}$, number of grains per cob, 1000 grains weight, number of grain rows per cob, cob girth, and cob length were maximized $(P<0.001)$ at the N4 level without having an interaction with the $\mathrm{H}$ of maize crop. It was concluded that the selection of best $\mathrm{H}$ for each location at $325 \mathrm{~kg} \mathrm{~N} \mathrm{ha}^{-1}$ can be used to enhance the efficiency of maize yield in autumn season at both locations under irrigated conditions.
\end{abstract}

Keywords: Zea mays, Agronomic characters, Nitrogen, yield, Yield components

\section{How to cite this:}

Imran M, Ali A and Safdar ME, 2021. The impact of different levels of nitrogen fertilizer on maize hybrids performance under two different environments. Asian J. Agric. Biol. 2021(4): 202010527. DOI: https://doi.org/10.35495/ajab.2020.10.527

This is an Open Access article distributed under the terms of the Creative Commons Attribution 3.0 License. (https://creativecommons.org/licenses/by/3.0), which permits unrestricted use, distribution, and reproduction in any medium, provided the original work is properly cited.

\section{Introduction}

Maize is the world's most important and highest yielding staple food crop after wheat and rice in many developing countries (FAO, 2010). It is important both for human consumption and as well as animal feed (Danish et al., 2019). Starch is the main component of maize (Eltelib et al., 2006; Masood et al., 2011). It contains valuable unsaturated fatty acids and it is also one of the main sources for edible oil in Pakistan (Khan et al., 2013). Research is needed to enhance maize yield and to find the most promising hybrids of maize under stress environments and to evaluate their agronomic performance (Mubeen et al., 2013; 2016).

Nitrogen $(\mathrm{N})$ is a crucial plant nutrient and major 
yield factor that is essential for plant growth, development and ultimately impacts final yield. It plays a major role in many physiological processes such as chlorophyll development and a principal component of various enzymes, nucleic acids and proteins. Consequently, deficiency or an excess of $\mathrm{N}$ decreases the yield (Sharifi and Taghizadeh, 2009; Khan et al., 2014). An Enhancing level of $\mathrm{N}$ in the soil has been a major management strategy to attain highest yield (Zhu et al., 2016). N fertilizer is costly but is frequently required for optimum yield, so optimum levels of $\mathrm{N}$ are important for maximizing returns. However, demand of $\mathrm{N}$ changes varied from year to year and location to location, and so it is challenging to determine optimum level of $\mathrm{N}$ at the peak crop demand. (Shanahan et al., 2008). Best N management practices reduces loss of $\mathrm{N}$ and enhance availability of $\mathrm{N}$ for crops, which in turn improve nitrogen use efficiency and reduce the potential negative impact of $\mathrm{N}$ on the environment (Havlin et al., 2009).

Khaliq et al. (2008) reported that $\mathrm{N}$ is required in larger amounts as compared to other nutrients, so increasing levels of $\mathrm{N}$ have been shown to have a significant impact on grain yield. A research by Abbas et al. (2005) found that $\mathrm{N}$ application enhanced the cob number, thousand grains weight and number of grains. Crop yield also tend to increase with increasing $\mathrm{N}$ rates (Dahmardeh, 2011; Shrestha, 2013; Sharifi and Namvar 2016). A research by Khan et al. (2012) found that $\mathrm{N}$ application supplied adequate nutritional requirements for maize crop to grow rapidly and so promoted grain production. An optimal rate of $\mathrm{N}$ is required for maximum yield and grains weight (Wajid et al., 2007).

The $\mathrm{N}$ requirement for maize crop depends on type of soil, crop rotation, and weather conditions (Blackmer et al., 2009; Bundy et al., 2011). The mismanagement of plant nutrition leads to low productivity (Bakht et al., 2006). The quantity of irrigation and levels of $\mathrm{N}$ for optimum maize growth and yield have not been well described for arid environments that are characterized by high temperatures and low rainfall (Hammad et al., 2011; Hammad, 2018). Developing high yielding maize cultivars that have comparatively high grain protein content under low $\mathrm{N}$ stress is critical to ensure nutrition and food security (Arisede et al., 2020). The average maize yield of Pakistan is extremely low compared to developed countries, and an imbalanced supply of nutrients is considered one of the major causes for the limitations in yield (Khan et al., 2014). Although a number of experiments have been conducted in Pakistan to determine the optimum amount of $\mathrm{N}$ for maize, but the research which has been conducted was insufficient to simultaneously determine the impact of $\mathrm{N}$ on maize hybrids by split applications, methods and timings of application. The objective of this study was therefore, to determine the impact of five different levels of $\mathrm{N}$ on yield and yield components of different autumn maize hybrids in two different environments.

\section{Material and Methods}

\section{Study site}

A field study was conducted at the agriculture research farm of college of agriculture, university of Sargodha, Punjab which is located at a latitude $32.04^{\circ} \mathrm{N}$ and a longitude $72.62^{\circ} \mathrm{E}$ and at NARC Islamabad Latitude 33.68 and Longitude 73.04 during the years 2017 and 2018. Sargodha has a semi-arid subtropical climate and is known for its world-renown canal system to supply water for supplemental irrigation and NARC Islamabad has humid subtropical climate. Most soils are deficient in nitrogen. The soil at the experimental site of Sargodha was a sandy loamy with well drained, moderately calcareous and alkaline characteristics while NARC Islamabad site was loamy soil. Composite soil samples to a depth of $30 \mathrm{~cm}$ were obtained from the experimental site using a soil auger prior to sowing. Soil analysis indicated that these two sites had a $\mathrm{pH}$ near 8.0 and were rated as deficient in the main elements i.e., N, P and K. Table 1 and Table 2 shows various characteristics of different soil.

\section{Weather}

Standard weather data including daily maximum and minimum air temperature $\left({ }^{\circ} \mathrm{C}\right)$, rainfall $(\mathrm{mm})$ and daily sunshine (hours) were recorded for each location and each year, with the help of weather station of Pakistan Meteorological Department, Sargodha and NARC Islamabad. Figure 1 shows means of weather variables during 2017 and 2018. 
Muhammad Imran et al

Table-1. Soil physical and chemical characteristics of the experimental site Sargodha

\begin{tabular}{|c|c|c|c|c|c|c|}
\hline \multirow{3}{*}{ Soil Characteristics } & \multicolumn{6}{|c|}{ Soil sample depth } \\
\hline & \multicolumn{2}{|c|}{$15 \mathrm{~cm}$} & \multicolumn{2}{|c|}{$20 \mathrm{~cm}$} & \multicolumn{2}{|c|}{$30 \mathrm{~cm}$} \\
\hline & 2017 & 2018 & 2017 & 2018 & 2017 & 2018 \\
\hline Soil pH & 7.9 & 8.0 & 7.9 & 8.0 & 8.0 & 8.1 \\
\hline Organic matter \% & 1.32 & 1.30 & 1.32 & 1.30 & 1.02 & 1.00 \\
\hline Total Soil N (\%) & 0.066 & 0.071 & 0.066 & 0.071 & 0.048 & 0.052 \\
\hline Available P $\left(\mathrm{mg} \mathrm{kg}^{-1}\right)$ & 7.5 & 7.7 & 7.5 & 7.7 & 9.8 & 9.9 \\
\hline Available $\mathrm{K}\left(\mathrm{mg} \mathrm{kg}^{-1}\right)$ & 164 & 170 & 164 & 168 & 140 & 144 \\
\hline Texture & Sandy loam & Sandy loam & Sandy loam & Sandy loam & Sandy loam & Sandy loam \\
\hline
\end{tabular}

Table-2. Soil physical and chemical characteristics of the experimental site NARC Islamabad

\begin{tabular}{|c|c|c|c|c|c|c|}
\hline & \multicolumn{6}{|c|}{ Soil sample depth } \\
\hline Soil Characteristics & \multicolumn{2}{|c|}{$15 \mathrm{~cm}$} & \multicolumn{2}{|c|}{$20 \mathrm{~cm}$} & \multicolumn{2}{|c|}{$30 \mathrm{~cm}$} \\
\hline & 2017 & 2018 & 2017 & 2018 & 2017 & 2018 \\
\hline Soil pH & 7.85 & 7.8 & 7.82 & 7.9 & 8.0 & 8.1 \\
\hline Organic matter $\%$ & 1.21 & 1.25 & 0.92 & 0.94 & 0.62 & 0.63 \\
\hline Total Soil N (\%) & 0.071 & 0.071 & 0.054 & 0.071 & 0.044 & 0.049 \\
\hline Available $\mathrm{P}\left(\mathrm{mg} \mathrm{kg}^{-1}\right)$ & 6.4 & 6.5 & 5.5 & 5.5 & 4.8 & 4.9 \\
\hline Available $\mathrm{K}\left(\mathrm{mg} \mathrm{kg}^{-1}\right)$ & 82 & 86 & 71 & 73 & 66 & 67 \\
\hline Texture & loam & loam & loam & loam & loam & loam \\
\hline
\end{tabular}

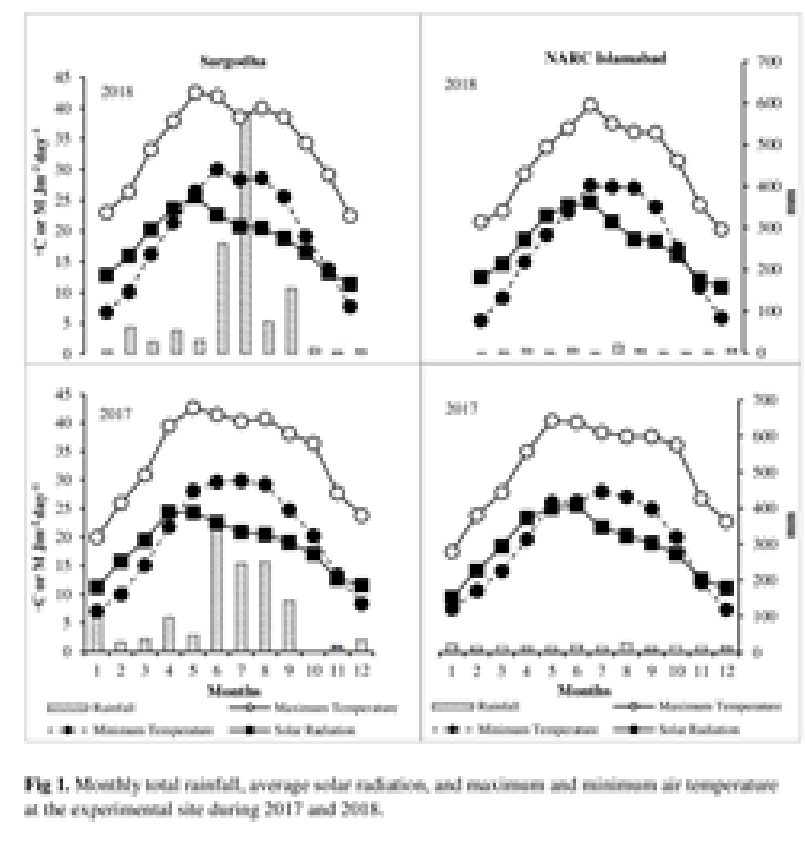

\section{Cultural practices}

The experiment was laid out in a randomized complete block design (RCBD) using a split plot and three replications; the net plot size was $6 \mathrm{~m} \times 3 \mathrm{~m}$. Nitrogen levels were randomized in the main plots and maize hybrids in the sub plots. The experiment was consisting of five levels of $\mathrm{N}\left(\mathrm{N}_{1}=100 \mathrm{~kg} \mathrm{~N} \mathrm{ha}^{-1}\right.$, $\mathrm{N}_{2}=175 \mathrm{~kg} \mathrm{~N} \mathrm{ha}^{-1}, \mathrm{~N}_{3}=250 \mathrm{~kg} \mathrm{~N}^{-1}, \mathrm{~N}_{4}=325 \mathrm{~kg} \mathrm{~N}^{-1}$ $\mathrm{ha}^{-1}$ and $\mathrm{N}_{5}=400 \mathrm{~kg} \mathrm{~N} \mathrm{ha}^{-1}$ ) and three different maize hybrids $\left(\mathrm{H}_{1}=\mathrm{P}-3939, \mathrm{H}_{2}=30-\mathrm{T}-60\right.$, and $\mathrm{H}_{3}=30-\mathrm{Y}-$ 87). The soil was analyzed before sowing and after harvesting. Crops were sown in 2017 and 2018 in autumn season on $60 \mathrm{~cm}$ spaced ridges with a plantto-plant distance of $20 \mathrm{~cm}$. Phosphorus (P) was applied as DAP at a rate of $115 \mathrm{~kg} \mathrm{ha}^{-1}$; potassium (K) was applied as SOP $\left(\mathrm{K}_{2} \mathrm{SO}_{4}\right)$ at a rate of $75 \mathrm{~kg} \mathrm{ha}^{-}$ ${ }^{1}$ at the time of sowing. One third of nitrogen was applied at the time of sowing, while the remaining two-thirds of $\mathrm{N}$ was applied in two splits, the first at 15 days after sowing and the second at flowering. A total of eight irrigations were applied during the growing season such as first furrow irrigation 100 $\mathrm{mm}$ and another 7 furrow irrigations of $75 \mathrm{~mm}$. All other cultural practices, such as hoeing, weeding, and plant protection measures were kept uniform for all individual plots.

\section{Data collection}

The data were collected according to standard procedures. The crop was harvested manually at full maturity. Each sub plot area was $6 \mathrm{~m} \times 3 \mathrm{~m}$. At physiological maturity data on plant height $(\mathrm{cm})$ was recorded from base to the tip of tassel with the help of meter rod by selecting randomly 10 plants from each plot and then average was calculated. For the cobs length 10 plants were randomly selected and their cobs lengths were measured with the help of measuring tape in $\mathrm{cm}$ and then calculated its average. Cobs from randomly selected 10 plants were 
removed and their girth $(\mathrm{cm})$ with the help of Vernier Caliper were measured in $\mathrm{cm}$ and then averaged. Grain rows/cob of ten randomly selected cobs from each plot were counted and were averaged. Grains/cob was counted from 10 randomly selected cobs from each plot and was averaged. In each plot the total number of selected cobs in $\mathrm{m}^{-2}$ area were collected and threshed and grains $/ \mathrm{m}^{-2}$ were calculated and its average was taken. After final threshing, 1000 grains were taken randomly from seed lot of each plot and was weighted with the help of electronic balance and 1,000 grain weight $(\mathrm{g})$ was measured. Three central rows of each treatment were harvested, dried, threshed and weighted and then was converted into grain yield $\left(\mathrm{kg} \mathrm{ha}^{-1}\right)$.

Grain yield $=$ Grain yield per three rows $\times 10000$ No. of rows $\times$ row length $\times$ R-R distance

\section{Statistical analysis}

Data were analyzed using the MIXED procedures of SAS (version 9.4, SAS/STAT, SAS Institute Inc., Cary, NC). The data on growth and characteristics of yield were tested based on the distribution of the residuals using Shapiro-Wilk and homogeneity of variance. A pooled analysis was conducted out within the location across years/seasons (Gomes and Gomes, 1984). The statistical models included the following parameters: the fixed impacts of levels of nitrogen, hybrid, interactions between nitrogen and hybrid, and the random effect of year. The Kenward-Roger method was used to calculate the approximate denominator degrees of freedom to compute F-tests in the statistical models. The Tukey adjustment was applied to account for multiple comparisons. In all analyses, single degrees of freedom of orthogonal polynomial contrasts of interest using contrast statement including the linear and quadratic effects of levels of nitrogen were also evaluated. The mixed models were computed to generate least squares means \pm standard error of the mean $(\mathrm{LSM} \pm \mathrm{SEM})$ of the response variables. Tables and figures were made according to the LSM \pm SEM generated from the mixed models based on the fixed and random effects of the models. Statistical significance was considered at $\mathrm{P} \leq 0.05$.

\section{Results and Discussion}

\section{Plant height}

Huge difference was observed between nitrogen rates, hybrids and locations. Optimum $\mathrm{N}$ levels and its splits application is important for maize yield which is also suggested by experiments. Its application is more important for soil which is usually deficient in nitrogen such as our country Pakistan. Plant height was improved by application of $\mathrm{N}$ levels and with application timing. The effect of year on plant height was statistically significant at both sites. The maximum plant height was observed in 2018 at Sargodha $7 \%(175 \mathrm{~cm})$ compared to 2017 $(164 \mathrm{~cm})$ while plant height at NARC Islamabad during 2018 was $3 \%(182 \mathrm{~cm})$ as compared to 2017 $(177 \mathrm{~cm})$ (Table 3).

For hybrids significant differences in plant height was found, maximum plant height was observed for Sargodha $(185 \mathrm{~cm})$ in $30-Y-87$ and at NARC Islamabad $(181 \mathrm{~cm}$ at par with hybrid P-3939, 179 $\mathrm{cm})$. The difference in plant height was due to the genetic nature of different hybrids. The $\mathrm{N}$ rate had a significant effect on plant height. The plots fertilized with N4 had the greatest plant height at Sargodha $(196 \mathrm{~cm})$, which was statistically at par with N3 (187 $\mathrm{cm})$, but for NARC Islamabad greatest plant height was recorded $(187 \mathrm{~cm}$ which was followed by $\mathrm{N} 3$ $185 \mathrm{~cm}$ ) while the minimum heights of plant at Sargodha and NARC Islamabad $(140 \mathrm{~cm}$ and 151 $\mathrm{cm}),(169 \mathrm{~cm})$ were observed in plots fertilized at rates of N1 and N2, respectively (Table 3). Imran et al. (2015) also reported that an increase in the $\mathrm{N}$ rate resulted in increase in plant height, the main parameter which helps in the determination of growth during the growing season. The increase in plant height was due to the increasing $\mathrm{N}$ levels.

The comparison between locations, means of plant height was lower 6\% $(169 \mathrm{~cm})$ at Sargodha than at NARC Islamabad $(179 \mathrm{~cm})$. The difference in means for both locations were due to environmental factors such as temperature and soil conditions. Gross et al. (2006) endorsed that for the positive effects on plant height and maize grain yield that $\mathrm{N}$ should be applied in one or two application during the season only. An interaction between levels of $\mathrm{N}$ and $\mathrm{H}$ tended to be non-significant for both locations $(P<0.09)$ and $(p<$ $0.2776)$. The plant height for both locations (196 and $187 \mathrm{~cm})$ was maximized $(P<0.001)$ at $\mathrm{N} 4$ level in maize crop. 
Table-3. Effect of different $\mathbf{N}$ fertilizer levels on growth, yield and yield components of maize hybrids

\begin{tabular}{|c|c|c|c|c|c|c|c|c|}
\hline Treatment & \multicolumn{2}{|c|}{ Plant height (cm) } & \multirow{2}{*}{\multicolumn{2}{|c|}{$\begin{array}{c}\text { Cob length }(\mathrm{cm}) \\
\text { Sargodha } \\
\text { Islamabad } \\
\end{array}$}} & \multirow{2}{*}{\multicolumn{2}{|c|}{$\begin{array}{c}\text { Cob Girth }(\mathbf{c m}) \\
\text { Sargodha } \\
\text { Islamabad } \\
\end{array}$}} & \multicolumn{2}{|c|}{ Grain Rows per Cob } \\
\hline Locations & Sargodha & Islamabad & & & & & Sargodha & Islamabad \\
\hline \multicolumn{9}{|l|}{ A) Year } \\
\hline 2017 & $164 \mathrm{~b}$ & $177 \mathrm{~b}$ & $17.44 \mathrm{~b}$ & $15.29 \mathrm{~b}$ & $3.77 \mathrm{~b}$ & $3.73 \mathrm{~b}$ & $12.23 \mathrm{~b}$ & $12.94 \mathrm{~b}$ \\
\hline 2018 & $175 \mathrm{a}$ & $182 \mathrm{a}$ & $18.66 \mathrm{a}$ & $16.34 \mathrm{a}$ & $4.08 \mathrm{a}$ & $4.33 \mathrm{a}$ & $13.17 \mathrm{a}$ & $13.98 \mathrm{a}$ \\
\hline Tukey HSD & 6.6 & 2.02 & 0.8 & 1.5 & 0.3 & 0.08 & 0.8 & 3.34 \\
\hline Significance & * & $* *$ & $*$ & $* *$ & * & $* *$ & $*$ & ** \\
\hline \multicolumn{9}{|c|}{ B) Nitrogen Levels } \\
\hline N1 & $140 \mathrm{c}$ & $169 \mathrm{~d}$ & $16.41 \mathrm{~b}$ & $14.63 \mathrm{c}$ & $3.30 \mathrm{~d}$ & $3.85 \mathrm{c}$ & $10.81 \mathrm{~b}$ & $12.16 \mathrm{~d}$ \\
\hline $\mathrm{N} 2$ & $151 \mathrm{c}$ & $175 \mathrm{c}$ & $16.94 \mathrm{~b}$ & $15.3 \mathrm{bc}$ & $3.62 \mathrm{c}$ & $3.98 \mathrm{~b}$ & $11.46 \mathrm{~b}$ & $13.02 \mathrm{c}$ \\
\hline N3 & $187 \mathrm{ab}$ & $185 \mathrm{a}$ & $19.02 \mathrm{a}$ & $16.59 \mathrm{a}$ & $4.28 \mathrm{ab}$ & $4.14 \mathrm{a}$ & $13.73 \mathrm{a}$ & $14.04 \mathrm{~b}$ \\
\hline $\mathrm{N} 4$ & $196 \mathrm{a}$ & $187 \mathrm{a}$ & $19.75 \mathrm{a}$ & $16.76 \mathrm{a}$ & $4.41 \mathrm{a}$ & $4.18 \mathrm{a}$ & $14.36 \mathrm{a}$ & $14.76 \mathrm{a}$ \\
\hline N5 & $174 \mathrm{~b}$ & $180 \mathrm{~b}$ & $18.14 \mathrm{ab}$ & $15.8 \mathrm{~b}$ & $4.02 \mathrm{~b}$ & $4.01 \mathrm{~b}$ & $13.15 \mathrm{a}$ & $13.33 \mathrm{c}$ \\
\hline Tukey HSD & 16.0 & 4.18 & 2.0 & 0.73 & 0.2 & 0.1 & 1.4 & 0.58 \\
\hline Significance & ** & *** & ** & ** & $* *$ & ** & ** & ** \\
\hline \multicolumn{9}{|l|}{ C) Hybrids } \\
\hline \multicolumn{9}{|c|}{ Autumn season hybrids } \\
\hline $\mathrm{H} 1=\mathrm{P}-3939$ & $172 \mathrm{~b}$ & $179 \mathrm{ab}$ & $17.96 \mathrm{ab}$ & $15.85 \mathrm{ab}$ & $3.96 \mathrm{a}$ & $4.02 \mathrm{ab}$ & $12.71 \mathrm{ab}$ & $13.49 \mathrm{ab}$ \\
\hline $\mathrm{H} 2=30 \mathrm{~T} 60$ & $153 \mathrm{c}$ & $179 \mathrm{~b}$ & $17.80 \mathrm{~b}$ & $15.59 \mathrm{~b}$ & $3.79 \mathrm{~b}$ & $4.00 \mathrm{~b}$ & $12.36 \mathrm{~b}$ & $12.96 \mathrm{~b}$ \\
\hline $\mathrm{H} 3=30$ Y 87 & $185 \mathrm{a}$ & $181 \mathrm{a}$ & $18.4 \mathrm{a}$ & $16.01 \mathrm{a}$ & $4.04 \mathrm{a}$ & $4.07 \mathrm{a}$ & $13.04 \mathrm{a}$ & $13.94 \mathrm{a}$ \\
\hline Tukey HSD & 7.4 & 1.91 & 0.5 & 0.29 & 0.1 & 0.06 & 0.6 & 0.6 \\
\hline Significance & *** & * & * & $* *$ & *** & * & $*$ & ** \\
\hline Mean & 169.7 & 179.4 & 18.05 & 15.81 & 3.92 & 4.03 & 12.7 & 13.46 \\
\hline Interaction & NS & NS & NS & NS & NS & NS & NS & NS \\
\hline
\end{tabular}

\section{Cob length}

The year effect on cob length was statistically significant for both locations, with a maximum cob length of $18.6 \mathrm{~cm}$ was achieved at Sargodha in 2018 compared to $17.4 \mathrm{~cm}$ in 2017 and for NARC Islamabad, maximum cob length of $16.3 \mathrm{~cm}$ was recorded in 2018 as compared to $201715.2 \mathrm{~cm}$ (Table 3). Table 3 shows significant effect for hybrids, the maximum cob length was found for $\mathrm{H} 3$ at both locations $(18.4 \mathrm{~cm}$ and $16.01 \mathrm{~cm})$ which is at par with $\mathrm{H} 1$ for both locations $(17.9 \mathrm{~cm}$ and 15.8 $\mathrm{cm})$. Findings for cob length showed that the effects of $\mathrm{N}$ levels on cob length were highly significant, the greatest cob length was obtained for Sargodha at N4 $\mathrm{ha}^{-1}$, which was statistically at par with treatment N3 and $\mathrm{N} 5$, while minimum cob length was observed at $\mathrm{N} 1 \mathrm{ha}^{-1}$ and $\mathrm{N} 2$ but for NARC Islamabad greatest cob length was recorded at $\mathrm{N} 4$ and was statistically followed by N3. The interactive effect between $\mathrm{H}$ and levels of $\mathrm{N}$ was found to be statistically nonsignificant. These results match with those observed by Seadh et al. (2015) and Matusso and Materusse (2016), in which they concluded that $\mathrm{N}$ added to maize plants can enhance cob length. (Haile et al., 2012) concluded that $\mathrm{N}$ absorption was significantly enhanced particularly at the time of when $\mathrm{N}$ was utmost required for the crop and hence increase the cob length only due to optimum and efficient time of application. The comparison between locations, means of cob length was lower $13 \%(15.81 \mathrm{~cm})$ at NARC Islamabad than at Sargodha $(18.05 \mathrm{~cm})$. The difference in means for both locations were due to environmental factors such as rainfall and temperature during growing season because there was more rainfall during growing season at Sargodha than NARC Islamabad.

\section{Cob girth}

$\mathrm{N}$ management in maize production system is one of the basic concerns as it is the most important and primary nutrient for growth and development of the crop. Optimum rate and time of $\mathrm{N}$ application can increase yield productivity and nutrient use efficiencies while reducing pollution (Nielsen, 2013). The result from this study shows that the year effect on cob girth was statistically significant for both locations, i.e maximum cob girth attained during 2018 at Sargodha $(4.08 \mathrm{~cm})$ compared to $2017(3.77 \mathrm{~cm})$ while for NARC Islamabad during 2018, maximum cob girth was $(4.33 \mathrm{~cm})$ as compared to 2017 (3.73 
$\mathrm{cm})$. Differences were found to be significant among the $\mathrm{H}$, with $\mathrm{H} 3$, and $\mathrm{H} 1$, having maximum cob girth for Sargodha, $4.04 \mathrm{~cm}$ and $3.96 \mathrm{~cm}$ and for NARC Islamabad, $4.07 \mathrm{~cm}$ and $4.02 \mathrm{~cm}$, respectively.

While minimum cob girth was recorded in 30-T-60 for both locations $(3.79 \mathrm{~cm}$ and $4 \mathrm{~cm})$, as shown in Table 3. Differences for $\mathrm{N}$ levels were also highly significant, with maximum cob girth obtained at N4 for Sargodha $(4.41 \mathrm{~cm})$ which was statistically at par with N3 $(4.28 \mathrm{~cm})$ while for NARC Islamabad maximum cob girth was recorded at $\mathrm{N} 4(4.18 \mathrm{~cm})$ which was statistically at par with N3 $(4.14 \mathrm{~cm})$. The minimum girth for both locations was obtained at N1 (3.3 $\mathrm{cm}$ and 3.8) (Table 3). The comparison between locations, means of cob girth was lower $(3.9 \mathrm{~cm})$ at Sargodha than at NARC Islamabad $(4.03 \mathrm{~cm})$. These results are in accordance with those reported by Seadh et al. (2015) and Matusso and Materusse (2016) who found that supplemental $\mathrm{N}$ enhanced the cob girth of maize with increasing levels of $\mathrm{N}$.

\section{Grain rows per cob}

A clear difference was observed between nitrogen rates, hybrids and locations. Grain rows per cob is a vital yield component trait and increases the number of grains per cob. Maximum grain rows per cob was higher during 2018 for both Sargodha and NARC Islamabad locations (13.77 and 13.98) as compared to 2017 (12.2 and 12.9). There was a significant difference among the hybrids, with maximum number of grain rows/cob observed in $\mathrm{H} 3$ for both locations, H3 for Sargodha and NARC (13.0 and 13.9), which was at par with H1, (12.7 and 13.4), while minimum was found for $\mathrm{H} 2$, (12.3 and 12.9) (Table 3).

$\mathrm{N}$ application rates were also found to be significant. The highest number of grain rows per cob for Sargodha (14.3) was obtained at N4, which was at par with N3 (13.7) and N5 (13.1) while for NARC Islamabad maximum number of grain rows per cob was found at N4 (14.7), (Table 3). Thus, $\mathrm{N}$ added to maize enhances the cob girth which in turn increases the number of grain rows per cob. The comparison between locations, means of grain rows per cob was lower (12.7) at Sargodha than at NARC Islamabad (13.4). These results agree with those observed by Seadh et al. (2015) and Matusso and Materusse (2016).

\section{Number of grains per cob}

Wide difference was observed between nitrogen rates, hybrids and locations. The number of grains per cob is a contributing factor in the number of grains $\mathrm{m}^{-2}$. The year effect on the number of grains per cob was greater in 2018 for both Sargodha and NARC Islamabad locations (422 and 437) as compared to 2017 (401 and 408), (Table 4).

The impact of the hybrids on the number of grains per cob was highly significant at Sargodha and was significant at NARC Islamabad. The H3 had the highest maximum number of grains per cob for Sargodha (421) as compared to the other hybrids whereas for NARC Islamabad maximum number of grains per cob was maximum at $\mathrm{H} 3$ which was statistically at par with H1 (424).

Nitrogen and its application timings had significant effect on yield component of grains per cob of maize. The statistical analysis showed that the $\mathrm{N}$ application rates were found to be highly significant for both the locations. The highest number of grains per cob for Sargodha (451) was attained at N4 and for NARC Islamabad, highest number of grains per cob was found at N4 (453) which was followed by N3 (445), and the lowest number of grains per cob for both locations (360) and (378) occurred at N1.

These results are in agreement with the findings of Selassie (2015), Woldesentbet and Haileyesus (2016) and Achiri et al. (2017) who concluded that enhancing the $\mathrm{N}$ levels increased the number of grains per cob. The interaction between hybrids and levels of $\mathrm{N}$ was not statistically significant. The comparison between locations, means number of grains per cob was lower (411) at Sargodha than at NARC Islamabad (422). The difference in means for both locations were due to environmental factors such as rainfall and temperature because more rainfall occurred during growing season at Sargodha than at NARC Islamabad.

The number of grains per cob for Sargodha (451) was highest $(P<0.001)$ at N4 level and for NARC Islamabad (453) was highest $(p<0.0000)$ at N4 level followed by $\mathrm{N} 3$ (445) without having an interaction with the $\mathrm{H}$ of maize crop (Fig. 2A, 2B).

\section{Number of grains $\mathbf{~ m}^{-2}$}

Huge difference was observed between nitrogen rates, hybrids and locations. The number of grains $\mathrm{m}^{-}$ ${ }^{2}$ are essential parameter that contributes towards final yield of maize. The year effect on the total number of grains $\mathrm{m}^{-2}$ was significant at both locations, with the maximum number of Grains $\mathrm{m}^{-2}$ of 3329 during 2018 as compared to 3202 in 2017 at Sargodha while at NARC Islamabad, maximum number of grains $\mathrm{m}^{-2}$ (3546) in 2018 as compared to 2017 (3431). 
The highest number of grains $\mathrm{m}^{-2}$ was found for $\mathrm{H} 3$ at Sargodha (3446) and NARC Islamabad (3553) and the lowest number of grains was found with $\mathrm{H} 2$ (3077) and (3432).

With respect to $\mathrm{N}$ levels, the greatest number of grains was found for the treatment N4 at Sargodha (3688) and NARC (3732 followed by N3 3688), while the lowest number of grains was observed for N1 for Sargodha (2770) and for NARC (3154) (Table 4).

These results are in line with the findings of Qian et al. (2016) who concluded that $\mathrm{N}$ application significantly enhanced the number of grains $\mathrm{m}^{-2}$. Shrestha et al. (2018a) observed that high $\mathrm{N}$ levels and fertile soils were more important for maize hybrids as it was more responsive to $\mathrm{N}$.

The comparison between locations, means number of grains $\mathrm{m}^{-2}$ was lower 7\% (3265 at Sargodha than at NARC Islamabad 3488). The difference in means for both locations were due to environmental factors such as rainfall and temperature during growing season.

Total number of grains for Sargodha and NARC (3688 vs 3732) was highest $(P<0.001)$ and $(P<$ $0.000)$ at N4 level without having an interaction with the $\mathrm{H}$ of maize crop (Fig. 2C, 2D).

\section{0 grains weight}

1000 grains weight is an important contributing parameter for yield, which plays a key role in the potential of a cultivar. A clear difference was observed between hybrids, $\mathrm{N}$ levels and locations. In this study, the year effect on the 1,000 grains weight was statistically significant at both locations, with a higher 1,000 grains weight during 2018 at Sargodha $5 \%$ (298 vs $284 \mathrm{~g}$ ) and at NARC Islamabad 11\% (269 vs $240 \mathrm{~g}$ ) compared to 2017 (Table 4). The highest 1,000 grains weight at Sargodha location (298 g) was found for H3 compared to H1 (291 g) and $\mathrm{H} 2(283 \mathrm{~g})$ but at NARC Islamabad, the highest 1,000 grains weight (256 g) was found for both H3 and H1 (Table 4).

$\mathrm{N}$ and its application timings had significant effect on yield component of thousand grains weight of maize. With respect to nitrogen, the highest 1,000 grains weight at Sargodha (308 g) was recorded with application rates of $\mathrm{N} 4$, which was at par with $\mathrm{N} 3$ (304 g) and N5 (297 g) while for NARC Islamabad, the highest 1,000 grains weight recorded at N4 (265 g) followed by N3 (263 g) (Table 3).

Table-4. Effect of different $\mathbf{N}$ fertilizer levels on yield and yield components of maize hybrids

\begin{tabular}{|c|c|c|c|c|c|c|c|c|}
\hline \multirow{2}{*}{$\begin{array}{l}\text { Treatment } \\
\text { Locations }\end{array}$} & \multicolumn{2}{|c|}{ Number of Grains per cob } & \multicolumn{2}{|c|}{ Number of Grains $\mathbf{m}^{-2}$} & \multicolumn{2}{|c|}{1000 Grain weight $(\mathrm{g})$} & \multicolumn{2}{|c|}{ Yield (kg/ha) } \\
\hline & Sargodha & Islamabad & Sargodha & Islamabad & Sargodha & Islamabad & Sargodha & Islamabad \\
\hline \multicolumn{9}{|l|}{ A) Year } \\
\hline 2017 & $401 \mathrm{~b}$ & $408 \mathrm{~b}$ & $3202 \mathrm{~b}$ & $3431 \mathrm{~b}$ & $284 \mathrm{~b}$ & $240 \mathrm{~b}$ & $6851 \mathrm{~b}$ & $6352 \mathrm{~b}$ \\
\hline 2018 & $422 \mathrm{a}$ & $437 \mathrm{a}$ & $3329 \mathrm{a}$ & $3546 \mathrm{a}$ & $298 \mathrm{a}$ & $269 \mathrm{a}$ & $7555 \mathrm{a}$ & $6808 \mathrm{a}$ \\
\hline Tukey HSD & 9.5 & 13.2 & 125.4 & 69 & 12.4 & 1.13 & 285.2 & 4.1 \\
\hline Significance & $*$ & $*$ & $*$ & $*$ & $*$ & $* *$ & $* *$ & $* *$ \\
\hline \multicolumn{9}{|c|}{ B) Nitrogen Levels } \\
\hline N1 & $360 \mathrm{e}$ & $378 \mathrm{~d}$ & $2770 \mathrm{~d}$ & $3154 \mathrm{c}$ & $267 \mathrm{c}$ & $241 \mathrm{~d}$ & $5974 \mathrm{e}$ & $5728 \mathrm{~d}$ \\
\hline $\mathrm{N} 2$ & $382 \mathrm{~d}$ & $410 \mathrm{c}$ & $3020 \mathrm{c}$ & $3405 \mathrm{~b}$ & $279 \mathrm{~b}$ & $247 \mathrm{c}$ & $6616 \mathrm{~d}$ & $6157 \mathrm{~cd}$ \\
\hline N3 & $438 \mathrm{~b}$ & $445 \mathrm{a}$ & $3490 \mathrm{~b}$ & $3688 \mathrm{a}$ & $304 \mathrm{a}$ & $263 a b$ & $7830 \mathrm{~b}$ & $6999 \mathrm{~b}$ \\
\hline N4 & $451 \mathrm{a}$ & $453 \mathrm{a}$ & $3688 \mathrm{a}$ & $3732 \mathrm{a}$ & $308 \mathrm{a}$ & $265 \mathrm{a}$ & $8187 \mathrm{a}$ & $7485 \mathrm{a}$ \\
\hline N5 & $425 \mathrm{c}$ & $428 \mathrm{~b}$ & $3359 \mathrm{~b}$ & $3461 \mathrm{~b}$ & $297 \mathrm{a}$ & $258 \mathrm{~b}$ & $7406 \mathrm{c}$ & $6534 \mathrm{c}$ \\
\hline Tukey HSD & 10.4 & 16.7 & 146.1 & 193.8 & 12.1 & 5.7 & 319.4 & 464.6 \\
\hline Significance & $* *$ & $* *$ & $* *$ & $* *$ & $* *$ & $* *$ & $* *$ & $* *$ \\
\hline \multicolumn{9}{|l|}{ C) Hybrids } \\
\hline \multicolumn{9}{|l|}{$\begin{array}{c}\text { Autumn season } \\
\text { hybrids }\end{array}$} \\
\hline $\mathrm{H} 1=\mathrm{P}-3939$ & $412 \mathrm{~b}$ & $424 \mathrm{ab}$ & $3274 \mathrm{~b}$ & $3480 \mathrm{ab}$ & $291 \mathrm{~b}$ & $256 a$ & $7202 b$ & $6574 \mathrm{ab}$ \\
\hline $\mathrm{H} 2=30 \mathrm{~T} 60$ & $400 \mathrm{c}$ & $417 \mathrm{~b}$ & $3077 \mathrm{c}$ & $3432 \mathrm{~b}$ & $283 c$ & $251 \mathrm{~b}$ & $6788 \mathrm{c}$ & $6397 \mathrm{~b}$ \\
\hline $\mathrm{H} 3=30 \mathrm{Y} 87$ & $421 \mathrm{a}$ & $427 \mathrm{a}$ & $3446 \mathrm{a}$ & $3553 \mathrm{a}$ & $298 \mathrm{a}$ & $256 \mathrm{a}$ & $7617 \mathrm{a}$ & $6770 \mathrm{a}$ \\
\hline Tukey HSD & 4.8 & 9.7 & 70.9 & 76.8 & 3.5 & 3.8 & 276.4 & 250.4 \\
\hline Significance & $* *$ & $*$ & $* *$ & $* *$ & $* *$ & $* *$ & $* *$ & $* *$ \\
\hline Mean & 411.4 & 422.7 & 3265 & 3488 & 291.1 & 254.6 & 7203 & 6580 \\
\hline Interaction & NS & NS & NS & NS & NS & NS & NS & NS \\
\hline
\end{tabular}


El-Shahed et al. (2017) observed similar responses regarding the effect of $\mathrm{N}$ on vegetative growth, which in turn favored metabolic processes and increased growth and maize yield attributes. Seadh et al. (2015) and Matusso and Materusse (2016) found that the addition of $\mathrm{N}$ increased grain rows per cob, the number of grains per cob and 1,000 grains weight. The 1,000 grains weight at Sargodha and NARC Islamabad $(308 \mathrm{~g})$ and $(265 \mathrm{~g})$ was highest $(P<$ $0.001,0.0035)$ at $\mathrm{N} 4$ level without having an interaction with the $\mathrm{H}$ of maize crop (Fig. $2 \mathrm{E}$ and 2F).

The comparison between both locations, 1,000 mean grains weight was lower (291 g) at NARC Islamabad than at Sargodha (254 g). Differences in means of 1000 grains weight at both locations were due to different daily variations in maximum and minimum temperatures and rainfall over two years as well as other variations in the environment.

\section{Grain yield}

There was a very clear difference observed between hybrids, nitrogen rates and locations. Experiments showed that optimum $\mathrm{N}$ rates and its splits application is important for maize yield. Its application is more important in Pakistan as our soil is usually deficient in nitrogen. The results from this study presented that year effect on grain yield of maize $\mathrm{H}$ were statistically highly significant at both Sargodha and NARC Islamabad locations. The grain yield was recorded $10 \%$ (6851 vs 7,555 $\mathrm{kg} \mathrm{ha}^{-1}$ ) and $7 \%$ (6352 vs $6808 \mathrm{~kg} \mathrm{ha}^{-1}$ ) more at both locations in 2018 than 2017 (Table 4). Differences in yield between years ascribed due to daily variations in temperatures, different patterns of rainfall, relative humidity and other temporal variations in the environment as well as interaction between environmental parameter, crop management, and genetics over these two years.

Hybrid differences in yield were highly significant at both locations with similar trend, the results indicated that highest grain yield was found for H3 (Sargodha, $7,617 \mathrm{~kg} \mathrm{ha}^{-1}$ ) and (NARC 6,770 $\mathrm{kg} \mathrm{ha}^{-1}$ followed by $\mathrm{H} 1$ producing $6,574 \mathrm{~kg} \mathrm{ha}^{-1}$ ), while $\mathrm{H} 2$ produced the lowest grain yield at Sargodha $\left(6,788 \mathrm{~kg} \mathrm{ha}^{-1}\right)$ and NARC $\left(6,397 \mathrm{~kg} \mathrm{ha}^{-1}\right)$.

The differences for the different $\mathrm{N}$ application rates were highly significant. At Sargodha and NARC $\left(8,187\right.$ and $\left.7,485 \mathrm{~kg} \mathrm{ha}^{-1}\right)$ the highest grain yield was observed for the N4 application rate, while the lowest grain yield was obtained with $\mathrm{N} 1$ application rate at
Sargodha and NARC (5,974 and 5,728 $\left.\mathrm{kg} \mathrm{ha}^{-1}\right)$. These results substantiate the findings of Selassie (2015), Woldesentbet and Haileyesus (2016) and Achiri et al. (2017) who observed similar effects of $\mathrm{N}$ levels on yield in maize, as well as Qian et al. (2016), who found that $\mathrm{N}$ fertilization increased grain yield significantly for different maize hybrids. Regarding yield, in different experiments increases maize grain yield with the application of increasing $\mathrm{N}$ level (Kappes et al., 2014; Galindo et al., 2016), For supporting the results of the present research.

The comparison between means of grain yield at both locations was relatively lower $\left(6,580 \mathrm{~kg} \mathrm{ha}^{-1}\right)$ at NARC Islamabad than at Sargodha $\left(7,203 \mathrm{~kg} \mathrm{ha}^{-1}\right)$. The difference in means grain yield for both locations were due to environmental factors such as rainfall and temperature during growing season. At $\mathrm{N} 4$ level the grain yield for both locations $\left(8,187\right.$ and $\left.7,485 \mathrm{~kg} \mathrm{ha}^{-1}\right)$ was highest $(P<0.001$ and $P<0.000)$ without having an interaction with the $\mathrm{H}$ of maize crop (Fig. $2 \mathrm{G}$ and $2 \mathrm{H}$ ).
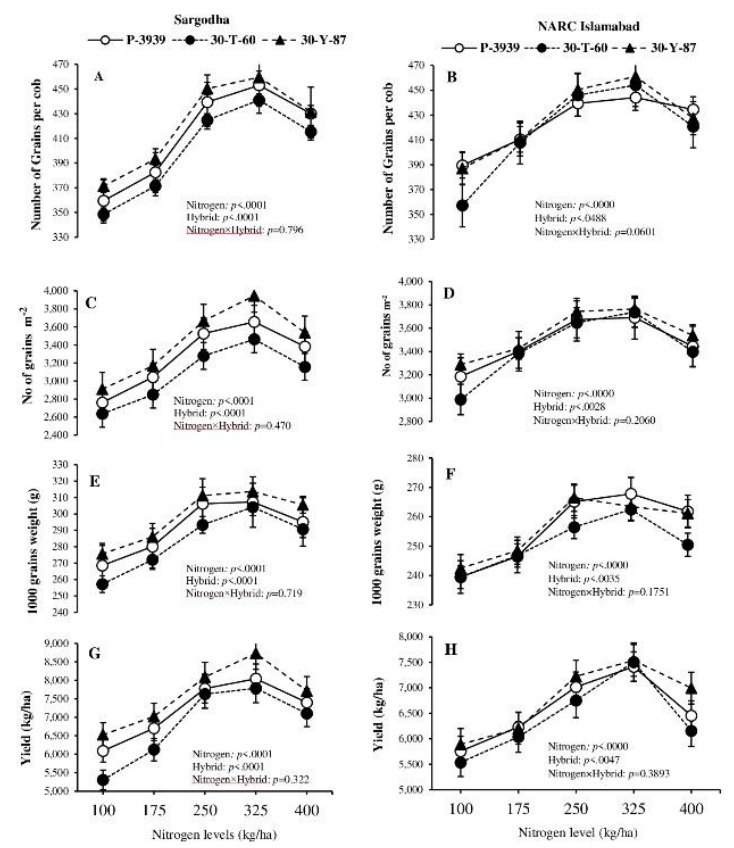
Fig 2. Fertilizer response for two years for di
Sargodha and NARC Islamabad with HSD at $5 \%$.

\section{Conclusion}

The results obtained from this experiment shows that in autumn season under irrigated conditions at two different environments, highest yield and yield 
components for different maize hybrids were achieved for a $\mathrm{N}$ fertilizer rate of $325 \mathrm{~kg} \mathrm{~N} \mathrm{ha}^{-1}$ when one-third of a dose of $\mathrm{N}$ was applied at the time of sowing and the remaining two-thirds were applied in two splits, the first at 15 days after sowing and the second at flowering. Hence, N4 $\left(325 \mathrm{~kg} \mathrm{~N}^{-1}\right)$ is recommended for both environments under irrigated conditions.

\section{Acknowledgement}

The authors are grateful to ORIC, University of Sargodha for providing a research grant (financial support) for this study.

Disclaimer: None.

Conflict of Interest: None.

Source of Funding: None.

\section{References}

Abbas G, Hussain A, Ahmad A and Wajid SA, 2005. Effect of irrigation schedules and nitrogen rates on yield and yield components of maize. J. Agric. Soc. Sci. 1(4): 335-338.

Achiri DT, Mbaatoh MH and Njualem D, 2017. Agronomic and yield parameters of $\mathrm{CHC} 202$ maize (Zea mays L.) variety influenced by different doses of chemical fertilizer (NPK) in Bali Nyonga, North West Region Cameroon. Asian. J. Soil. Sci. Plant Nutri. 2(4): 1-9.

Arisede C, Mainassara Z, Jill C, Amsal T, Cosmos M, Bish D, Benhildah M, Mike O and Maruthi PB, 2020. Low-N stress tolerant maize hybrids have higher fertilizer $\mathrm{N}$ recovery efficiency and reduced $\mathrm{N}$-dilution in the grain compared to susceptible hybrids under low N conditions. Plant. Prod. Sci. J. 23(4): 417-426.

Bakht J, Ahmad S, Tariq M, Akber H and Shafi M, 2006. Response of maize to planting methods and fertilizer N. J. Agric. Biol. Sci. 1: 8-14.

Blackmer AM, Pottker D, Cerrato ME and Webb J, 2009. Correlations between soil nitrate concentrations in late spring and corn yields in Iowa. American. Soc. Agron. 2: 103-109.

Bundy LG, Andraski TW, Ruark MD and Peterson AE, 2011. Long-term continuous maize and nitrogen fertilizer effects on productivity and soil properties. Agron. J. 103: 1346-1351.

Dahmardeh M, 2011. Effect of plant density and nitrogen rate on PAR absorption and maize yield. American. J. Plant. Physiol. 6(1): 44-49.

Danish S, Kiran S, Fahad S, Ahmad N, Ali MA, Tahir FA, Rasheed MK, Shahzada K, Xiulingg L, Wang D, Mubeen M, Abbas S, Tariq MM, Hashmi MZ, Adnan M, Saeed B, Saud S, Khan MN, Ullah A and Nasim W, 2019. Alleviation of chromium toxicity in maize by $\mathrm{Fe}$ fortification and chromium tolerant ACC deaminase producing plant growth promoting rhizobacteria. Ecotoxicol. Environ. Safety. 185: 109706.

https://doi.org/10.1016/j.ecoenv.2019.109706.

El-Shahed HM, Mowafy SA, Osman MMA and ElNaggar NZ, 2017. Physiological response of maize hybrids to nitrogen and phosphorus fertilization. Zagazig. J. Agric. Res. 44(1): 41-69.

Eltelib HA, Hamad MA and Ali EE, 2006. The effect of Nitrogen and Phosphorus fertilization on growth, yield and quality of forage maize (Zea mays L.). J. Agron. 5: 515-518.

FAO, 2010. Agricultural production statistics. Available: http://faostat.fao.org.

Galindo FS, Filho, MCMT, Buzetti S, Santini JMK, Alves CJ, Nogueira LM, Ludkiewicz MGZ, Andreotti M and Bellotte JLM, 2016. Maize yield and foliar diagnosis affected by nitrogen fertilization and inoculation with Azospirillum brasilense. Rev. Bras. Cienc. Solo 40: e015036. DOI:10.1590/18069657rbcs20150364.

Gomes KA and Gomes AA, 1984. Statistical Procedures for Agricultural Research book. Wiley-Inter Science, John Wiley and Sons, New York, USA.

Gross MR, Pinho RGV and Brito AH, 2006. Nitrogen fertilization, sowing rate and interrow spacing in maize crop in no-tillage system. Cienc. Agrotec. 30: 387-393. DOI: 10.1590/S141370542006000300001.

Haile D, Nigussie D and Ayana A, 2012. Nitrogen use efficiency of bread wheat: effects of nitrogen rate and time of application. J. Soil Sci. Plant. Nutri. 12(3): 389-409.

Hammad HM, 2018. Offsetting land degradation through nitrogen and water management during maize cultivation under arid conditions. Land. Degrad. Develop. J. 29(5): 1366-1375.

Hammad HM, Ahmad A, Khaliq T, Farhad W and Mubeen M, 2011. Optimizing rate of nitrogen application for higher yield and quality in maize under semiarid environment. Crop. Environ. 2(1): 38-41.

Havlin JH, Beaton JD, Tisdale SL and Nelson WL, 2009. 
Soil fertility and fertilizers, $7^{\text {th }}$ Edition. New Delhi, PHIL Earning, Private Limited.

Imran S, Arif M, Khan A, Khan MA, Shah W and Latif A, 2015. Effect of nitrogen levels and plant population on yield and yield components of maize. Adv. Crop. Sci. Tech. 3(2): 2-7.

Kappes C, Arf O, Bem EAD, Portugal JR and Gonzaga $A R, 2014$. Nitrogen management in maize crop under no-tillage system. Rev. Bras. Milho Sorgo 13: 201-217. DOI:10.18512/19806477/rbms.v13n2p201-217.

Khaliq T, Ahmad A, Hussain A, Ranjha AM and Ali MA, 2008. Impact of nitrogen rates on growth, yield, and radiation use efficiency of maize under varying environments Pakistan. J. Agric. Sci. 45(3): 1-7.

Khan F, Khan S, Fahad S, Faisal S, Hussain S, Ali S and Ali A, 2014. Effect of different levels of nitrogen and phosphorus on the phenology and yield of maize varieties. Am. J. Plant. Sci. 5: 2582-2590.

Khan N, Khan NW and Khan IA, 2012. Integration of nitrogen fertilizer and herbicides for efficient weed management in maize (Zea mays L.) crop. Sarhad J. Agric. 28: 457-463.

Khan S, Awan IU, Baloch MS, Khan EA, Khakwani AA and Hussain N, 2013. Performance of maize varieties under irrigated conditions of Dera Ismail Khan. G. Uni. J. Res. 29: 26-31.

Masood T, Gul R, Munsif F, Jalal F, Hussain Z, Noreen N, Khan H, Nasiruddin and Khan H, 2011. Effect of different phosphorus levels on the yield and yield components of maize. Sarhad J. Agric. 27: 167-170.

Matusso J and Materusse M, 2016. Growth and yield response of maize (Zea mays L.) to different nitrogen levels in acid soils. Acad. Res. J. Agric. Sci. Res. 4(2): 35-44.

Mubeen M, Ahmad A, Wajid A and Bakhsh A, 2013. Evaluating different irrigation scheduling criteria for autumn-sown maize under semi-arid environment. Pak. J. Bot. 45(4): 1293-1298.

Mubeen M, Ahmad A, Wajid A, Khaliq T, Hammad HM, Sultana SR, Ahmad S, Nasim W and Fahad S, 2016. Application of CSM-CERES-Maize Model in optimizing irrigated conditions. Outlook on Agric. 45(3): 173-184.

Nielsen RB, 2013. Root Development in Young Corn, in, Purdue University Department of Agronomy.

Qian C, Yu Y, Gong X, Jiang Y, Zhao Y, Yang Z, Hao Y, Li L, Song Z and Zhang W, 2016. Response of grain yield to plant density and nitrogen rate in spring maize hybrids released from 1970 to 2010 in Northeast China. Crop. J. 4(6): 459-467.

Seadh SE, Abido WAE and Abdulrahman DR, 2015. The role of foliar application in reducing maize nitrogen requirements. J. Plant. Prod. 6(7): 11681180.

Selassie YG, 2015. The effect of $\mathrm{N}$ fertilizer rates on agronomic parameters, yield components and yields of maize grown on Alfisols of North-western Ethiopia. Environ. Sys. Res. 4(1): 1-7.

Shanahan JF, Kitchen NR, Raun WR and Schepers JS, 2008. Responsive in-season nitrogen management for cereals. Comp. Elect. Agric. 61: 51-62.

Sharifi RS and Namvar A, 2016. Effects of time and rate of nitrogen application on phenology and some agronomical traits of maize (Zea mays L.). Biologija. 62: 35-45.

Sharifi RS and Taghizadeh R, 2009. Response of maize (Zea mays L.) cultivars to different levels of nitrogen fertilizer. J. food. Agric. Environ. 3(4): 518-521.

Shrestha J, 2013. Effect of nitrogen and plant population on flowering and grain yield of winter maize. Sky. J. Agric. Res. 2: 64-68.

Shrestha J, Chaudhary A and Pokhrel D, 2018a. Application of nitrogen fertilizer in maize: a review. Peruv. J. Agron, 2(2): 22-26.

Wajid A, Ghaffar A, Maqsood M, Hussain K and Nasim $\mathrm{W}, 2007$. Yield response of maize hybrids to varying nitrogen rates. Pak. J. Agric. Sci. 44(2): 217-220.

Woldesentbet M and Haileyesus A, 2016. Effect of nitrogen fertilizer on growth, yield and yield components of maize (Zea mays L.) in Deacha District, South western Ethiopia. Int. J. Res. Granthaalayah. 4: 95-100.

Zhu S, Vivanco JM and Manter DK, 2016. Nitrogen fertilizer rate affects root exudation: the rhizosphere microbiome and nitrogen-use-efficiency of maize. Appl. Soil. Ecol. 107: 324-333.

\section{Contribution of Authors}

Safdar ME \& Ali A: Designed the research experiment, reviewed literature and helped in editing and write up of manuscript Imran M: Conducted experiments, collected and analysed data and wrote the manuscript 